\title{
Inosine Triphosphatase Deficiency
}

National Cancer Institute

\section{Source}

National Cancer Institute. Inosine Triphosphatase Deficiency. NCI Thesaurus. Code

C129974.

An inherited condition caused by mutation(s) in the ITPA gene, encoding inosine triphosphate pyrophosphatase. It is characterized by elevated concentrations of inosine triphosphate in erythrocytes. 